\title{
Fiscal policy and growth in a small emerging economy: The case of Bulgaria
}

\author{
DESISLAVA STOILOVA* (1) and NIKOLAY PATONOV
}

Faculty of Economics, South-West University "Neofit Rilski”, Blagoevgrad, Bulgaria

Received: August 23, 2019 • Revised manuscript received: February 29, 2020 - Accepted: June 11, 2020

Published online: September 02, 2020

(C) 2020 The Author(s)

\section{ABSTRACT}

The purpose of this article is to study the impact of fiscal policy on economic growth in Bulgaria for the period 1995-2018. The descriptive analysis is focused on the general trends in fiscal policy and tax structure. The influence of government spending and taxation on economic growth is studied through regressions on time-series data. The empirical estimates prove that taxation is a more reliable instrument of fiscal policy than government spending in terms of a small open emerging-market economy. The dilution of the effect of public spending is probably caused by the high negative values of the current account balance that have been maintained for long periods. Thus, when domestic supply is weak, government expenditure cannot stimulate domestic production, as supply is dominated by import goods. Public investments demonstrate a negative effect on economic growth, which suggests a low productivity of investment spending. A factor of great importance is the level of corruption, which is strongly correlated with government investments, but is harmful to their efficiency. The Bulgarian tax system demonstrates consistency with economic growth. The receipts from value-added tax seems growth-conductive. The decrease of the corporate income tax rate exerts a positive impact on economc performance during the analyzed period, while personal income taxation demonstrates a negative effect. Property taxation has no significant relation with the growth of the Bulgarian economy.

\section{KEYWORDS}

fiscal policy, tax structure, economic growth, Bulgaria

\section{JEL-CODES}

E62, H21, 047

\footnotetext{
*Corresponding author. E-mail: dstoilova@swu.bg
} 


\section{INTRODUCTION}

Contemporary fiscal policy pursues a variety of objectives. The tax system aims not just to raise the necessary funds for government expenditure, but also to contribute to income redistribution, economic stabilization, resource allocation, and most importantly to promote the economic growth. The purpose of the properly designed tax system is to achieve desired fiscal policy objectives in the most efficient way, namely by limiting undesired distortions, minimizing the cost of tax collection and supporting growth. In this way, the efficiency of taxation and particularly the tax structure plays an important role in achieving economic growth and fiscal consolidation.

The conventional economic theory predicts that taxation causes distortions and impacts negatively on economic growth. Considering a simple production function, it is apparent that taxation can affect growth through its impact on (1) physical capital, (2) human capital, and (3) through its effect on total factor productivity. Some studies argue that corporate and personal income taxes are the most detrimental to growth, while consumption, environment, and property taxes are less harmful (OECD 2008).

Having in mind, these assumptions, this article aims to study the basic trends in the fiscal policy in Bulgaria for the period 1995-2018 and its impact on the economic growth. In addition, the paper sheds light on the distribution of the tax burden as a factor for creating a growthfriendly environment. The article comprises six sections. Section 2 presents a brief literature review. Section 3 provides a descriptive analysis, focused on the general trends in fiscal policy and tax structure in Bulgaria, through a breakdown of the total tax revenues into standard components such as direct taxes, indirect taxes, and social security contributions. Section 4 presents the analytical framework and empirical methodology. Section 5 studies the effects of government spending and taxation on economic growth applying this methodology. Section 6 concludes the article.

\section{LITERATURE REVIEW}

The empirical studies on the relationship between fiscal policy and economic growth are focused primarily on providing evidence on the impact of the government spending and tax level on growth, and second, on the impact of the tax structure on growth. A number of studies (Agell et al. 2006; Barro 1990, 1991; Christie 2012; Chu et al. 2018; Easterly - Rebelo 1993; Engen Skinner 1992; Folster - Henrekson, 2001; Gemmell et al. 2016; Kneller et al. 1999; Koester Kormendi 1989; Levine - Renelt 1992; Oyinlola et al. 2020; Paparas - Richter 2015) have investigated the link between the overall level of public spending or total tax burden and economic growth using cross-country growth regression models covering different periods and various samples of countries. However, no clear consensus about the nature and significance of such a relationship has emerged from these works. This is not surprising, having in mind that the overall size of the public sector has two opposite effects. On the one hand, higher taxes cause potentially higher distortions and impact negatively on economic activity and growth, but on the other hand, higher taxes suppose higher levels of public expenditure, some of which may foster economic growth. 
The discussion on the impact of the tax structure on growth is mainly focused on the relative merits of direct vs indirect taxes, and especially on their ability to create a more growth-friendly environment. The prevailing view favors indirect taxation and suggests a shift of the fiscal burden toward indirect taxes, especially those on consumption. For example, Myles (2009) reviews the findings on the topic and concludes that almost all the results support the claim that a move from income taxation to consumption taxation will raise the rate of growth. Moreover, a general tendency to shift the fiscal burden from direct to indirect taxation, and in particular from labor and capital toward consumption taxes, has been observed in some of the EU member states over the last years (European Commission 2011).

The results from the empirical analyses of Kneller et al. (1999), Widmalm (2001), Lee and Gordon (2005), Gemmell et al. (2006), Vartia (2008), Arnold (2008), Schwellnus and Arnold (2008), Dackehag and Hansson (2012), Bernardi (2013), Canavire-Bacarreza et al. (2013), Szarowska (2013), Tanchev (2016), and Stoilova (2017) shed light on the nature and significance of the relationship between tax structure and growth.

Kneller et al. (1999) used a panel of 22 OECD countries for the period 1970-1995 and identified a depressing effect of so called "distortionary taxes," which include taxes on income and property. These findings are further confirmed by the analysis of Gemmell et al. (2006), which provided new evidence on the long-run impact of distortionary taxes on growth in OECD countries by updating and extending datasets to cover 1970-2004. Lee and Gordon (2005) applied cross-country regressions and found a significant negative correlation between statutory corporate tax rates and growth for 70 countries during 1970-1997. Dackehag and Hansson (2012) reported similar results. They studied how statutory tax rates on corporate and personal income affect economic growth in 25 rich OECD countries using panel data for the period 1975-2010, and found that both taxation of corporate and personal income negatively influence economic growth. The empirical analyses of Schwellnus and Arnold (2008) and Vartia (2008), based on large datasets of firms and industries across OECD countries, also indicated a negative effect of corporate taxes on the productivity and investment.

Widmalm (2001) used pooled cross-sectional data from 23 OECD countries, between 1965 and 1990, and found evidence that the proportion of tax revenue raised by taxing personal income has a negative correlation with economic growth. Arnold (2008) entered indicators of the tax structure into a set of panel growth regressions for a sample of 21 OECD countries over the period 1971-2004 and found that property taxes are the most growth-friendly, followed by consumption taxes and then by personal income taxes. At the same time, corporate income taxes appear to have the most negative effect on growth.

Szarowska (2013) applied regression analysis on annual panel data for EU-24 member states during the period 1995-2010 and found a statistically significant positive effect of consumption taxes on GDP growth. Ayoub and Mukherjee (2019) investigated the role of value-added tax (VAT) on economic growth in China using time series data for the period 1985-2016 and found a significant positive relationship.

In contrast to these findings, Bernardi (2013) has performed an aggregated analysis of tax trends across the Euro Area (EA-17) member countries, and a disaggregated, country-bycountry analysis, with regard to the 2000-2014 period. He found that the gains from a tax shift (from direct to indirect taxes) do not appear to be as straightforward as claimed by previous research. On the contrary, he predicts that the tax shift may exacerbate the economic slump spreading across the European Union, particularly as an effect of the general adoption of restrictive fiscal policies by almost all member countries. 
Canavire-Bacarreza et al. (2013) evaluated the effect of different tax instruments on growth for Latin American countries using vector autoregressive techniques and panel data estimation. They found that personal income tax does not have the expected negative effect on economic growth. For corporate income tax, their results suggest that reducing tax evasion and greater reliance on collection may boost economic growth in the region. The reliance on consumption taxes has significant positive effects on growth in Latin American in general, although they found slight negative effects in some of the selected countries.

Stoilova (2017) studied the impact of taxation on economic growth in the EU-28 member states for the period 1996-2013 through regressions on pooled panel data. She found that imposing VAT affects EU-28 economies negatively, and concluded that a tax system based on selective consumption taxes, taxes on personal income and property are more supportive to economic growth. Ahmad et al. (2013) investigated the impact of tax revenue on economic growth in Pakistan using time series data for the period of 1976-2011 and concluded that direct taxes should be increased (rather than indirect taxes) to support the economic prosperity of the country. Tanchev (2016) conducted an econometric study using the Ordinary Least Squares (OLS) method to assess the impact of the personal income tax on economic growth in Bulgaria for the period 2004-2012. He found that progressive income taxation has a positive impact on growth.

\section{DYNAMICS OF TAX REVENUES AND GOVERNMENT EXPENDITURE IN BULGARIA (1995-2018)}

The Republic of Bulgaria is a unitary state with 7.0 million inhabitants and a territory of 111,000 $\mathrm{km}^{2}$. It is situated in the Southeast Europe on the Balkan Peninsula. According to the World Bank's classification, Bulgaria has an emerging market economy in the upper-middle income range, where the private sectors account for more than $80 \%$ of the gross domestic product (GDP) (World Bank 2019). After deindustrialization of the economy, typical for the transition period, the service sector is the engine of economic growth, contributing to $65.6 \%$ of the gross value added, compared with the other sectors such as industry and agriculture, that contribute, respectively, to 28.1 and $6.3 \%$ of the gross value added (National Statistical Institute 2019). The financial market is gradually developing (Stoykova - Paskaleva 2018). The currency board, installed in 1997, is still in force. It was accepted as an emergency measure after a severe banking crisis and a period of hyperinflation. The currency board allows Bulgaria to issue its own currency (Bulgarian lev) that trades at a fixed exchange rate with the euro ( $1 \mathrm{EUR}=1.95583$ BGN). The Bulgarian currency is entirely backed by euro reserves and is fully convertible into euros (Todorov 2014). Thus, in addition to being a small open emerging economy, Bulgaria is also facing the challenge of how to promote growth, while maintaining a currency board arrangement.

A factor of major importance for the economic development of Bulgaria in the last decade was accession to the European Union in 2007. Unfortunately, the accession coincided with the global economic and financial crisis, which hit Bulgaria in 2009 and interrupted the considerable annual GDP growth of 6-7\% registered during the period 2002-2008. After the crisis, the growth is moderate and does not exceed 3-4\% per year. Despite the economic growth and the optimistic expectations around EU accession, the comparative analysis shows that Bulgaria reports the lowest GDP per capita among all the EU-28 member states (Eurostat 2019a). For the 
period 2007-2018, Bulgarian GDP per capita has not exceeded 50\% of the EU-28 average, which is almost 1.5 times lower than the values reported by Estonia, Lithuania, Poland, Slovakia, Croatia, and Hungary, almost twice lower than the Czech Republic and Slovenia, three times lower compared to Belgium, Denmark, Netherlands, Germany, Ireland, Austria, and Sweden, and 5.5 times lower than Luxembourg. Bulgaria used to compare favorably with Romania, but in 2018, even Romania achieved GDP per capita equal to 64\% of the EU average. It is obvious that Bulgaria needs a growth-friendly fiscal policy.

After the introduction of the currency board, the fiscal policy of Bulgarian governments has been always targeted toward a balanced budget. However, there were a few fiscal years that ended with budgetary deficit (see Fig. 1), namely 2009-2011, due to the global economic crisis and 2014, due to the bankruptcy of the Corporate Commercial Bank. In 2014, the government had to provide support to several other banks (to prevent a huge banking crisis) and to the Deposit Guarantee Fund (to pay back the personal and corporate deposits). As a result of the fiscal policy aimed at balanced budgets, the government debt has decreased from $303 \%$ of GDP in 1997 to only $16 \%$ in 2007 and $22.6 \%$ in 2018 (Ministry of Finance 2019), which is far below the $60 \%$ threshold imposed by the Maastricht criteria.

It is noticeable that during the analyzed period, total government expenditure in Bulgaria ranged around $35 \%$ of the GDP, which is far below the EU average (45-50\% of GDP). Government spending demonstrates cyclical dynamics over the period. The most apparent increase in government spending is seen during the periods of crisis.

The Bulgarian tax system comprises the standard components such as direct taxes (corporate income tax and personal income tax) and indirect taxes (VAT, excise duties, and customs duties), as well as taxes defined as "local" (i.e., property tax, inheritance tax, donations tax, tax on property purchase, vehicles tax, patent tax, tourist tax, and tax on taxi transport) which form

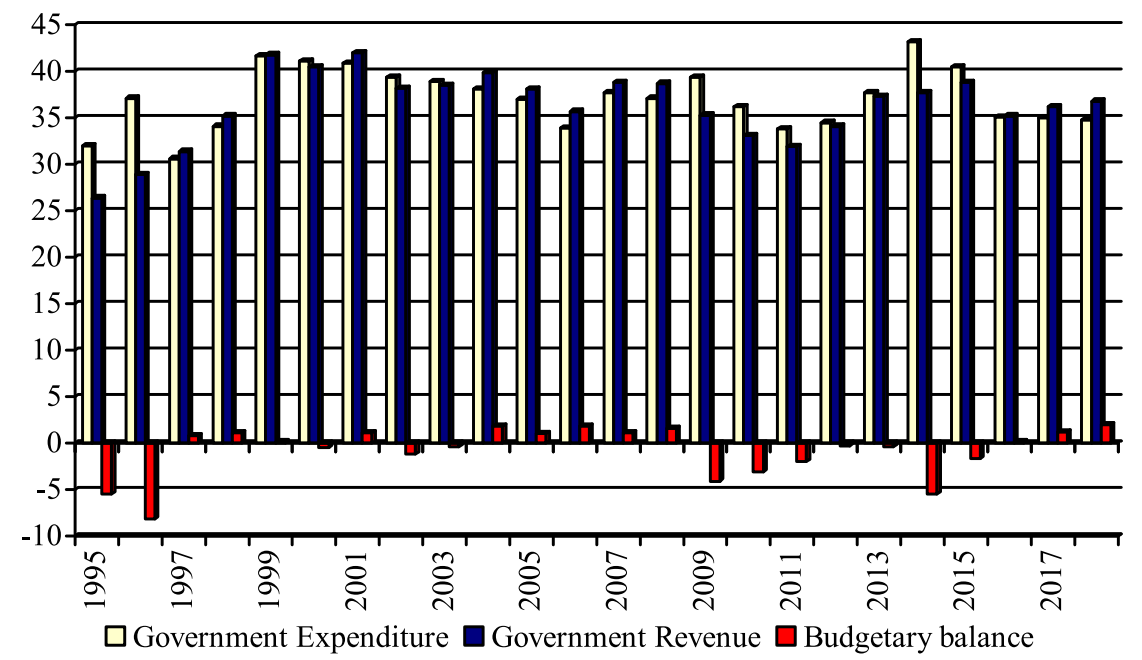

Fig. 1. Government Expenditure, Revenue, and Budgetary Balance in Bulgaria (\% of GDP). Source: Eurostat 
$16-17 \%$ of the local governments' budgets. Although many in numbers, the local taxes have little importance in the national tax system. Local tax revenues account for a negligible part (up to $3 \%$ ) of the total tax revenues and hardly exceed 1\% of GDP. One of the main reasons is the low tax base for the property tax, as he so-called "tax assessment" is far below the market value of the property. The same low base is also used for the calculation of inheritance tax, donation tax, and tax on property purchase. Another reason is the extremely large number of tax exemptions: for example, for properties used as basic residences of their owners, only $50 \%$ of the property tax is payable. Having in mind that $83.6 \%$ of Bulgarian population live in own homes (Eurostat 2019b), it is clear that a large group of taxpayers bears a highly reduced tax burden.

The main tendency of the tax policy in Bulgaria during the analyzed period is the decrease of income tax rates (see Fig. 2) with the intention to stimulate economic activity and attract foreign direct investments. For this purpose, the corporate tax rate was gradually decreased from $40 \%$ in 1997 to $10 \%$ in 2007 . This rate has not been changed during the last 12 years and is one of the lowest corporate income tax rates in the European Union. At the same time, the fiscal role of corporate income tax as a revenue source of the budget decreased from 4.7 to $2 \%$ of GDP (Ministry of Finance 2019). Another major tax reform is the transition from progressive to proportional personal income taxation. A flat tax rate of $10 \%$ was adopted in 2008 and replaced the progressive taxation with tax rates between 20 and 38\%. At the same time, the fiscal role of the personal income tax has not changed much and varies around 3\% of GDP (Ministry of Finance 2019). This is due to the abolishment of the nontaxable income. Now even persons with minimal salaries pay income tax.

Due to the outlined reforms that diminish the role of the income taxation, the Bulgarian tax system is based extremely on consumption taxes, namely VAT and excise duties, which form the prevalent part of consolidated state revenue. It is noticeable that the indirect taxes on consumption yield three times more than the direct taxes on income and property. Moreover, Bulgaria demonstrates the lowest direct-taxes-to-GDP ratio (6.2\%) across the EU-28. At the

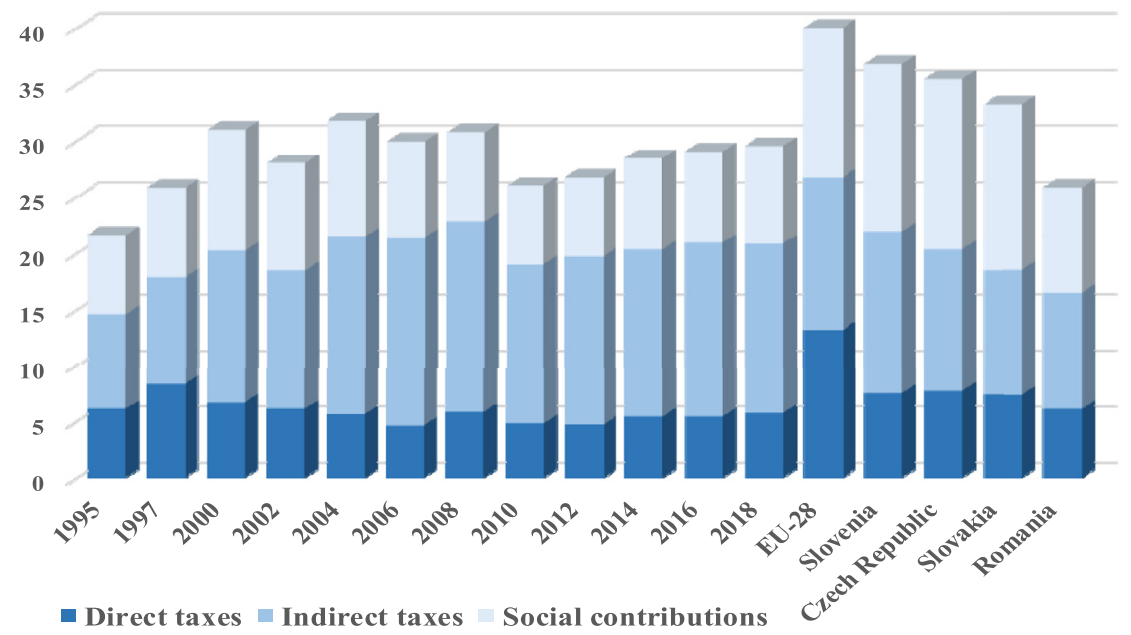

Fig. 2. Trends in the distribution of total tax burden in Bulgaria (\% of GDP). Source: Eurostat 
same time, the total tax burden in Bulgaria ranges from 25 to $30 \%$ of GDP and is much lower than the average tax burden for the EU-28 (40.2\%). The total tax burden in Bulgaria is comparative to the values reported by Romania (25.8\%), but is below the total tax burden in Slovenia (36.8\%), Slovakia (33.2\%), and the Czech Republic (35.4\%).

\section{EMPIRICAL METHODOLOGY AND DATA}

The article uses a regression analysis to study the impact of fiscal policy on economic growth in Bulgaria. The empirical study follows the common approach applied in most of the studies on this topic. The conventional simple specification tries to explain economic growth by government revenues and spending. Such a limited model is not inevitably intended to explain economic growth by all its ingredients, but to stress the impact of the instruments of fiscal policy on economic growth. Thus, the estimates are expected to have rather demonstrative character than a definitive one.

The regression Eq. (1) has the following summarized structure:

$$
y_{t}=\beta_{0}+\beta_{1} G D P_{t-1}+\beta_{2} T R_{t}+\beta_{3} T S_{t}+\beta_{4} I C_{t}+\varepsilon_{t}
$$

where the dependent variable $\left(y_{t}\right)$ is the annual growth rate of Bulgaria's gross domestic product in nominal terms, and the independent variables are the annual value of the GDP in the previous year $\left(\mathrm{GDP}_{t-1}\right)$, the total amount of tax revenues collected per fiscal year as a ratio to GDP $\left(\mathrm{TR}_{t}\right)$, and the total government expenditure per fiscal year as ratio to GDP $\left(\mathrm{TS}_{t}\right)$. The component $\mathrm{IC}_{t}$ describes the annual value of the index of corruption published by Transparency International. The parameters of the model are marked with $\beta_{0}, \beta_{1}, \beta_{2}, \beta_{3}$, and $\beta_{4}$. $\varepsilon_{t}$ marks the error term.

In addition to the basic analysis, the variables of total tax receipts and spending are replaced by disaggregate revenue and spending items. This approach was applied by Muir and Weber (2013) to estimate the multipliers of different spending and tax items. In this study, the total tax revenues are replaced with the receipts from VAT, excise duties, property taxes, taxes on corporate profit, and personal income. In this way, we can examine the relationship of each tax item with economic growth. The replacement of total government spending with the amounts of current and investment expenditure enables us to conclude about the efficiency of each type of expenditure as a policy instrument.

The technique of OLS is adopted for estimating the parameters of the regression model. Descriptive statistics of main variables is presented before the regression estimations (Table 1). The correlation matrix of main variables of the regression model is provided in Table 2. Hypotheses for bilateral causal relations is tested using by the procedure of Granger (Table 4). The study covers annual data for the period 1995-2018, retrieved from the databases of Eurostat, Transperancy International Bulgaria, 2020 the Ministry of Finance and National Statistical Institute of the Republic of Bulgaria.

\section{REGRESSION RESULTS}

The descriptive statistics on the main variables of Eq. (1) are presented in Table 1. The empirical distributions of all the variables are different from a normal symmetric distribution, but the 
Table 1. Descriptive statistics on the variables of the regression model

\begin{tabular}{|l|c|c|c|c|}
\hline & TR & TS & IC & GR \\
\hline Mean & 28.36 & 37.1 & 37.68 & 6.55 \\
\hline Median & 28.85 & 37.1 & 40.00 & 7.08 \\
\hline Maximum & 31.7 & 43.1 & 43.00 & 33.96 \\
\hline Minimum & 21.6 & 30.6 & 29.00 & -32.46 \\
\hline Std. Dev. & 2.58 & 3.17 & 4.77 & 11.44 \\
\hline Skewness & -0.93 & -0.05 & -0.80 & -1.10 \\
\hline Kurtosis & 3.27 & 2.35 & 2.27 & 7.78 \\
\hline Jarque-Bera & 3.55 & 0.43 & 3.23 & 27.71 \\
\hline Probability & 0.17 & 0.81 & 0.20 & 0.00 \\
\hline Sum & 680.80 & 890.40 & 942.00 & 157.12 \\
\hline Sum Sq. Dev. & 153.69 & 231.56 & 547.44 & 3.012 .27 \\
\hline Observations & 24 & 24 & 24 & 24 \\
\hline
\end{tabular}

Source: Authors' calculations.

Jarque-Bera test rejects deviation from normal distribution for the independent variables. Nevertheless, there could be some weak nonlinear links between the variables in the regression equation that would decrease the efficiency of the OLS method.

The correlation matrix (Table 2) presents the correlations between pairs of variables included in the regression model. The coefficient of correlation between the independent variables (namely tax revenue and total government spending) exceeds 0.2 , which indicates multicollinearity. The correlation coefficients disclose a curious phenomenon, which is specific for developing countries. The tax revenues are more closely correlated with the growth of the Bulgarian economy than government spending. These results suggest that taxation is a more efficient instrument for fiscal impacts on the economic performance in Bulgaria.

Table 2. Correlation matrix of the variables

\begin{tabular}{|l|c|c|c|c|}
\hline Variable & GR & TS & TR & IC \\
\hline GR & 1.00 & -0.11 & 0.49 & 0.19 \\
\hline TS & -0.11 & 1.00 & 0.49 & 0.39 \\
\hline TR & 0.49 & 0.49 & 1.00 & 0.61 \\
\hline IC & 0.19 & 0.39 & 0.61 & 1.00 \\
\hline
\end{tabular}

Source: Authors' calculations. 
Table 3. Disaggregate correlation matrix

\begin{tabular}{|l|c|c|c|c|}
\hline & GR & PI & CE & IC \\
\hline GR & 1.000000 & 0.375355 & 0.436404 & 0.191534 \\
\hline PI & 0.375355 & 1.000000 & 0.273803 & 0.490805 \\
\hline CE & 0.436404 & 0.273803 & 1.000000 & 0.052349 \\
\hline IC & 0.191534 & 0.490805 & 0.052349 & 1.000000 \\
\hline
\end{tabular}

Source: Authors' calculations.

Corruption does not seem directly correlated with GDP growth, but exerts its influence through a relation to tax revenues and public spending. There is a strong correlation between the index of corruption and tax revenues, most probably due to tax evasion and suboptimal work of the tax administration in terms of tax collection. In addition, corruption is strongly correlated with government spending, mainly due to inefficiently high prices for low-quality goods and services, provided through public procurements. The disaggregate estimates (Table 3) show that corruption is strongly correlated with public investments (PI), but does not demonstrate significant correlation to current government expenditure (CE).

Table 4 presents the OLS estimates. The columns contain five variants of the model created under different combinations of variables. This manner of presentation enables us to estimate not only the effects of the factors under the full version of the model but also the impact of each independent variable in terms of one-factor specification.

Contrary to conventional economic theory, the regression results show a negative impact of government expenditure on the annual GDP growth rate, while the impact of the tax receipts is positive and reliably expressed. Although unconventional, these results are supported by a variety of studies. Barro (1991) analyzed (among other variables) the ratio of real government consumption expenditure to real GDP as a regressor, and found a significantly negative correlation with growth for 98 countries in the period 1960-1985. Paparas and Richter (2015) applied regressions to highlight the relationship between fiscal policy and economic growth in the EU-15 for the period 1995-2008 and found a negative impact of spending on human capital accumulation on economic growth. At the same time, they noted that an increase in government spending on infrastructure has a significant positive impact on the economic growth of a country. Andersen and Jordan (1968) have estimated a weak positive effect of government expenditure in the quarters in which spending increases, but the effects are negative in the other quarters. They consider these results as consistent with modern quantity theories, which hold that government spending, taxing, and borrowing policies would have, through interest rate and wealth effects, different impacts on economic activity under varying circumstances.

Engen and Skinner (1992) used data from 107 countries during the period 1970-1985 and concluded that an increase in government spending reduces the output growth rates. Schaltegger and Torgler (2006) concentrated on the relationship between public expenditure and economic growth in Switzerland using the full sample of state and local governments for the period 19812001 and found a fairly robust negative relationship. Negative signs of the expenditure coefficients are estimated by a World Bank study conducted for a sample of transition countries in 
Table 4. OLS Estimations of the Bulgarian Fiscal Multipliers for the period 1995-2018

\begin{tabular}{|l|c|c|c|c|c|}
\hline Variable & Model 1 & Model 2 & Model 3 & Model 4 & Model 5 \\
\hline Constant & $-54.63^{* *}(-2.33)$ & $20.87(0.73)$ & $-10.755(-0.56)$ & $-21.12(-0.80)$ & $-51.27(-1.42)$ \\
\hline TR & $2.16^{* *}(2.62)$ & & & $3.40^{* * *}(3.31)$ & $4.14^{* * *}(3.49)$ \\
\hline TS & & $-0.39(-0.51)$ & & $-1.60^{* *}(-2.22)$ & $-1.39 *(-1.82)$ \\
\hline IC & & & $0.46(0.91)$ & $-0.24(-0.47)$ & $-0.20(-0.38)$ \\
\hline GDP(-1) & & & & & $-0.11(-0.55)$ \\
\hline$R$-squared & 0.24 & 0.01 & 0.03 & 0.40 & 0.45 \\
\hline Adj. R-squared & 0.20 & -0.03 & -0.01 & 0.31 & 0.33 \\
\hline Durbin-Watson & 2.55 & 1.75 & 2.02 & 2.44 & 1.94 \\
\hline F-statistic & 6.85 & 0.26 & 0.83 & 0.48 & 3.71 \\
\hline Prob(F-statistic) & 0.02 & 0.62 & 0.36 & 23 & 0.02 \\
\hline Observations & 23 & 23 & 23 & & 23 \\
\hline
\end{tabular}

Source: Authors' calculations.

Note: $t$ statistics in parentheses.

${ }^{* * *}$ significant at $1 \% ;{ }^{* *}$ significant at $5 \% ;{ }^{*}$ significant at $10 \%$. 
Table 5. Pairwise Granger Causality tests on the variables of Eq. (1)

\begin{tabular}{|l|c|c|c|}
\hline Null Hypothesis: & Obs & F-Statistic & Prob. \\
\hline TR does not Granger Cause TS & 22 & 2.05896 & 0.1582 \\
\hline TS does not Granger Cause TR & & 0.21563 & 0.8082 \\
\hline GDP does not Granger Cause TS & 22 & 5.87580 & 0.0115 \\
\hline TS does not Granger Cause GDP & & 0.94047 & 0.4098 \\
\hline GDP does not Granger Cause TR & 22 & 0.92002 & 0.4175 \\
\hline TR does not Granger Cause GDP & & 4.07566 & 0.0358 \\
\hline GDP does not Granger Cause IC & 22 & 1.19949 & 0.2864 \\
\hline IC does not Granger Cause GDP & & 1.25383 & 0.2761 \\
\hline
\end{tabular}

Source: Authors' calculations.

Note: lags: 2.

Eastern Europe and Central Asia (Gray et al. 2007). Moreover, they found that the effects of government expenditures that are under $35 \%$ of GDP are insignificant.

Chu et al. (2018) examined the growth effects of government expenditure compositions for a panel data set of 37 high-income and 22 low-to middle-income countries for the period 19932012. In both groups of countries, they found that increased levels of government expenditure have a negative impact on growth, while a change in the expenditure mix toward productive forms of expenditure and away from nonproductive forms of expenditure enhances economic growth.

The literature does not provide a consensus about the nature and significance of the relationship between taxation and growth. However, our results are in compliance with those of several studies. Mobilizing a dynamic panel data specification over the period 1989-2012, Nantob (2014) found that weak and high tax rates respectively at short run and long run do not create distortions and hence affect economic growth positively in eight West-African countries. Aghion et al. (2016) studied the relationships between taxation, corruption, and economic growth using state- and county-level variations within the United States over the 1983-2007 period, and reported a significantly positive marginal effect of taxation for growth for a state with low levels of corruption. Gashi et al. (2018) found that most of the taxes have a positive impact on the economic growth of Kosovo in the period 2007-2015.

The level of corruption does not demonstrate a clear influence on economic growth in Bulgaria. The regression coefficient is statistically insignificant in all the specifications of the model. It is positive in multiple regressions and negative in one-factor estimates. This is due to the multidirectional impact of corruption on government revenues and spending. On the one hand, corruption tends to diminish tax revenues, mainly due to suboptimal tax collection. On the other hand, it tends to increase public spending, but significantly harms its efficiency. It is generally accepted that corruption is a social evil, which is harmful to economic growth, but the quantitative studies face difficulties in finding a straightforward link between these two variables. Mauro (1996) even estimated positive and significant regression coefficients for the direct 
Table 6. Disaggregate estimations

\begin{tabular}{|l|c|c|c|}
\hline Variable & Model 1 & Model 2 & Model 3 \\
\hline Constant & $57.06(1.05)$ & $-12.71(-0.77)$ & $0.97(0.02)$ \\
\hline GDP(-1) & $-0.40^{* *}(-2.37)$ & $-0.13(-0.85)$ & $-0.50^{* *}(-2.13)$ \\
\hline Current expenditure & $-5.21(-1.24)$ & $1.84(1.17)$ & \\
\hline Investment Expenditure ${ }^{-1}$ & $-30.65^{* *}(-4.15)$ & $-24.63^{* * *}(-4.11)$ & \\
\hline Excise Duties $^{2}$ & $-0.94^{*}(-1.98)$ & & $-0.27(-0.42)$ \\
\hline Value Added Tax $^{-1}$ & $-470.92^{* *}(-2.30)$ & & $-407.55(-1.39)$ \\
\hline Corporate Profits Tax & $6.46^{* *}(2.27)$ & & $5.37(1.35)$ \\
\hline Personal Income Tax & $-0.01^{*}(-1.85)$ & & $-0.01(-1.53)$ \\
\hline Property Taxes & $-41.86(-0.64)$ & & $-36.62(-0.74)$ \\
\hline Index of Corruption ${ }^{-1}$ & $1894.57^{* *}(2.34)$ & $647.49(1.06)$ & $2058.78^{*}(1.77)$ \\
\hline$R$-squared & 0.79 & 0.60 & 0.51 \\
\hline Adjusted $R$-squared & 0.65 & 0.51 & 0.29 \\
\hline Durbin-Watson & 2.03 & 2.08 & 1.43 \\
\hline F-statistic & 5.71 & 6.95 & 2.30 \\
\hline Prob(F-statistic) & 0.00 & 0.00 & 0.08 \\
\hline Observations & 23 & 23 & 23 \\
\hline
\end{tabular}

Source: Authors' calculations.

Note: $t$ statistics in parentheses.

*** significant at $1 \%$; ** significant at $5 \%$; significant at $10 \%$.

impact of the corruption index on economic growth and investment in terms of a wide crosscountry panel. Several other studies also expressed views in favor of the idea that corruption could have a positive impact on growth (Aidt et al. 2008; Ebben - Vaal 2011). At the same time, the study of Boikos (2016) found negative impacts of corruption on the main ingredients of economic development, such as public spending on education and investments in physical capital. The results of d'Agostino et al. (2016) show that the interactions between corruption and investment and military spending have a strong negative impact on economic growth.

The regression relationships have not been impacted by Granger causal relations. The regression results are free of fake increases in the explanatory power of the estimates that could be due to causal links. Nevertheless, Table 5 shows that there is a strong causal relation from the tax revenue variable toward economic growth.

All the empirical estimates on the Bulgarian case prove that taxation is a more reliable instrument of fiscal policy than government spending in terms of a small open emerging-market economy. The dilution of the effects from government spending may be caused by the high negative values of the current account balance that have been maintained for long periods. Thus, 
when domestic supply is weak, government expenditure cannot stimulate domestic production if supply is dominated by import goods. The effects from this expenditure would be stronger in cases of strong domestic supply which has the potential to satisfy increased demand. Similar results have been shown in other studies on developing countries, conducted by Muir and Weber (2013), Ilzetzki (2011), Ilzetzki et al. (2011), and Patonov (2016).

The disaggregate estimations show interesting results. In the models in Table 6, total tax revenue and spending variables on were replaced by the main components of those variables. First, the estimates have been run on the full specification of the model. It includes the economic performance at first lag and both revenue and spending disaggregate items. For more details, the second model contains the main spending items, namely current and investment government expenditure. Inversely, the third model contains the receipts from basic taxes (VAT, excise duties, corporate profit tax, personal income tax, and property taxes). The theoretical values of the $F$-test in all the models have exceeded the corresponding empirical ones. There are, however, many nonlinear relations.

The results show that current government expenditure does not have a significant effect on economic growth, while government investments demonstrate a negative effect. This estimate suggests a low productivity of public investments. Factor of great importance is the level of corruption, which demonstrates a strong correlation with government investments, but is harmful to their efficiency. Although nonconventional, our results are in line with several other studies. Devarajan et al. (1996) used data from 43 developing countries over 20 years and found that an increase in the share of current expenditure has positive and statistically significant growth effects. By contrast, the relationship between the capital component of public expenditure and per-capita growth is negative. They concluded that seemingly productive expenditures, when used in excess, could become unproductive. Ghosh and Gregoriou (2008) found similar results. Using panel data for 15 developing countries over 28 years, they concluded that contrary to commonly held views, current spending has positive and significant effects on the growth rate, while the effects of capital spending seem negative.

The tax items demonstrate nonlinear relations with annual economic performance. The receipts from VAT seem consistent with the positive economic dynamics in Bulgaria during the analyzed period, as far as the relationship has an inverse form combined with a negative coefficient. This result is not surprising, having in mind that taxes on consumption (including VAT) are generally recommended as conducive to growth (Ayoub - Mukherjee 2019; OECD 2009, 2010; European Commission 2010; Zipfel - Heinrichs 2012; Macek 2014), due to the presumption that a tax system more heavily relying on consumption minimizes the distorting effects of taxation on growth factors (such as labor, capital, and technological progress). At the same time, the receipts from excise duties demonstrate a negative relation with the growth of Bulgarian economy. The coefficient loses its significance across the specifications, which could be caused by the absence of spending variables in the third model.

The coefficients that estimate the effects of the income taxes remain relatively stable, but their statistical significance changes across the models. The estimates confirm the consistency of corporate taxation's relationship with economic growth in Bulgaria. Obviously, the significant decrease of the corporate tax rate during the analyzed period (from 40 to 10\%) exerted a favorable influence on Bulgaria's economy. At the same time, the study found a negative impact of personal income taxation on economic growth in Bulgaria. This result could be explained in the light of the fundamental change in the model of individual income taxation during the 
analyzed period. On the surface, the tax rate was significantly reduced, from progressive rates, varying in the range $20-38 \%$, to $10 \%$ proportional rate. However, the fiscal role of the personal income taxation (around 3\% of GDP) did not change, due to the redistribution of the tax burden. Rejection of the nontaxable minimum income enhanced the taxable base and the number of taxpayers, including the persons from low-income groups whose disposable income and consumption have been reduced. On the other side, the individuals with higher incomes benefitted from this change, as far as they bear a reduced tax burden. This entails an increase in luxury consumption, inherent to this group of society. As luxury goods and services in a small open economy are mainly imported, it can be expected that increasing their consumption may have a negative effect on growth, in line with the decrease in the net export, as a component of GDP.

Confirmation of the depressing effects of income taxes on economic growth is found by Kneller et al. (1999), Widmalm (2001), Arnold et al. (2011), Dackehag and Hansson (2012), Macek (2014). On the opposite side are the results of Canavire-Bacarreza et al. (2013), Bernardi (2013), Havránek et al. (2015), and Tanchev (2016).

\section{CONCLUSIONS}

The empirical results prove that government expenditure in Bulgaria does not substantially contribute to increasing the annual GDP growth rate. In this respect, taxation is a more suitable instrument of fiscal policy than public spending, which seems a typical situation in terms of a small open emerging-market economy. The dilution of the effect of public spending is probably caused by the high negative values of the current account balance that have been maintained for long periods. Thus, when domestic supply is weak, government expenditure cannot stimulate domestic production, as supply is dominated by import goods. Public investments demonstrate a negative effect on GDP growth that suggests low productivity of investment spending. A factor of great importance is the level of corruption, which is strongly correlated with public investments, but is harmful to their efficiency.

Even though the analysis of the tax system is always a topical problem, the estimates provide evidence for the consistency of the relationship between value added taxation and economic growth. Corporate taxation exerts a favorable influence on the Bulgarian economy, due to the significant decrease of the corporate tax rate during the analyzed period (from 40 to $10 \%$ ). At the same time, personal income taxation demonstrates a negative impact on growth. As expected, property taxation has no significant relation with the development of Bulgarian economy.

\section{REFERENCES}

Agell, J. - Ohlsson, H. - Thoursie, P. (2006): Growth Effects of Government Expenditure and Taxation in Rich Countries: A Comment. European Economic Review 50(1): 211-218.

Aghion, P. - Akcigit, U. - Cagé, J. - Kerr, W. (2016): Taxation, Corruption and Growth. NBER Working Paper Series WP 21928. 
Ahmad, N. - Ahmad, A. - Yasmeen, K. (2013): The Impact of Tax on Economic Growth of Pakistan: An ARDL Approach. Journal of Basic and Applied Scientific Research 3(11): 392-398.

Aidt, T. - Dutta, J. - Senna, V. (2008): Governance Regimes, Corruption and Growth: Theory and Evidence. Journal of Comparative Economics 36: 195-220.

Andersen, L. - Jordan, J. (1968): Monetary and Fiscal Actions: A Test of Their Relative Importance in Economic Stabilization. Federal Reserve Bank of St. Louis Review 50: 24-44.

Arnold, J. (2008): Do Tax Structure Affect Aggregate Economic Growth? Empirical Evidence from a Panel of OECD Countries. OECD Economics Department Working Papers No. 643.

Arnold, J. - Brys, B. - Heady, C. - Johansson, A. - Schwellnus, C. - Vartia, L. (2011): Tax Policy for Economic Recovery and Growth. The Economic Journal 121(550): F59-F80.

Ayoub, Z. - Mukherjee, S. (2019): Value Added Tax and Economic Growth: An Empirical Study of China Perspective. Signifikan: Jurnal Ilmu Ekonomi 8(2): 235-242.

Barro, R. (1990): Government Spending in a Simple Model of Endogenous Growth. Journal of Political Economy 98: 103-125.

Barro, R. (1991): Economic Growth in a Cross-Section of Countries. Quarterly Journal of Economics 104: 407-444.

Bernardi, L. (2013): Recent Findings Regarding the Shift from Direct to Indirect Taxation in the EA-17. MPRA Paper No. 47877.

Boikos, S. (2016): Corruption, Public Expenditure and Human Capital, Accumulation. Review of Economic Analysis 8: 17-45.

Canavire-Bacarreza, G. - Martinez-Vazquez, J. - Vulovic, V. (2013): Taxation and Economic Growth in Latin America. IDB Working Paper No. IDB-WP-431.

Christie, T. (2012): The Effect of Government Spending on Economic Growth: Testing the Non-linear Hypothesis. Bulletin of Economic Research 66(2): 183-204.

Chu, T. - Hölscher, J. - McCarthy, D. (2018): The Impact of Productive and Non-productive Government Expenditure on Economic Growth: An Empirical Analysis in High-income Versus Low- to Middleincome Economies. Empirical Economics 58: 2403-2430.

D’Agostino, G. - Dunne J. - Pieroni, L. (2016): Government Spending, Corruption and Economic Growth. World Development 84: 190-205.

Dackehag, M. - Hansson, A. (2012): Taxation of Income and Economic Growth: An Empirical Analysis of 25 Rich OECD Countries. Lund University Department of Economics Working Paper No. 2012: 6.

Devarajan, S. - Swaroop, V. - Zou, H. (1996): The Composition of Public Expenditure and Economic Growth. Journal of Monetary Economics 37(2): 313-344.

Easterly, W. - Rebelo, S. (1993): Fiscal Policy and Economic Growth - An Empirical Investigation. Journal of Monetary Economics 32: 417-458.

Ebben, W. - Vaal, A. (2011): Institutions and the Relation Between Corruption and Economic Growth. Review of Development Economics 15: 108-123.

Engen, E. M. - Skinner, J. (1992): Fiscal Policy and Economic Growth. NBER Working Paper No. w4223. European Commission (2010): Fiscal Policy, Debt Reduction, and Growth after the Crisis, Chapter III of Public Finances in EMU. Brussels: European Commission.

European Commission (2011): Tax Reforms in EU Member States: Tax Policy Challenges for Economic Growth and Fiscal Sustainability. European Economy 5/2011.

Eurostat (2019a): Database. From https://ec.europa.eu/eurostat/data/database. (Accessed 25 July 2019). 
Eurostat (2019b): Data Explorer. Distribution of Population by Tenure Status, Type of Household and Income Group. http://appsso.eurostat.ec.europa.eu/nui/show.do?dataset=ilc_lvho02\&lang=en. (Accessed 16 July 2019).

Havránek, T. - Iršová, Z. - Schwarz, J. (2015): Dynamic Elasticities of Tax Revenue: Evidence from the Czech Republic. Czech National Bank Working Paper No. 8/2015.

Folster, S. - Henrekson, M. (2001): Growth Effects of Government Expenditure and Taxation in Rich Countries. European Economic Review 45: 1501-1520.

Gashi, B. - Asllani, G. - Boqolli, L. (2018): The Effect of Tax Structure on Economic Growth. International Journal of Economics and Business Administration 6(2): 56-67.

Gemmell, N. - Kneller, R. - Sanz, I. (2006): Fiscal Policy Impacts on Growth in the OECD: Are They Long-or Short-Term? Notthingham: University of Nottingham.

Gemmell, N. - Kneller, R. - Sanz, I. (2016): Does the Composition of Government Expenditure Matter for Long-run GDP Levels? Oxford Bulletin of Economics and Statistics 78(4): 522-547.

Ghosh, S. - Gregoriou, A. (2008): The Composition of Government Spending and Growth: Is Current or Capital Spending Better? Oxford Economic Papers 60(3): 484-516.

Gray, C. - Lane, T. - Varoudakis, A., eds. (2007): Fiscal Policy and Economic Growth. Lessons for Eastern Europe and Central Asia. Washington, DC: The World Bank.

Ilzetzki, E. (2011): Fiscal Policy and Debt Dynamics in Developing Countries. World Bank Policy Research Working Paper No. 5666.

Ilzetzki, E. - Mendoza, E. G. - Végh, C. A. (2011): How Big (Small?) Are Fiscal Multipliers? IMF Working Paper No. 11/52.

Kneller, R. - Bleaney, M. - Gemmell, N. (1999): Fiscal Policy and Growth: Evidence from OECD Countries. Journal of Public Economics 74: 171-190.

Koester, R. - Kormendi, R. (1989): Taxation, Aggregate Activity and Economic Growth: Cross-Country Evidence on Some Supply-side Hypotheses. Economic Inquiry 27(3): 367-386.

Lee, Y. - Gordon, R. (2005): Tax Structure and Economic Growth. Journal of Public Economics 89: 10271043.

Levine, R. - Renelt, D. (1992): A Sensitivity Analysis of Cross-country Growth Regressions. American Economic Review 82: 942-963.

Macek, R. (2014): The Impact of Taxation on Economic Growth: Case Study of OECD Countries. Review of Economic Perspectives 14(4): 309-328.

Mauro, P. (1996): The Effects of Corruption on Growth, Investment, and Government Expenditure: A Crosscountry Analysis. https://www.piie.com/publications/chapters_preview/12/4iie2334.pdf. (Accessed 25 July 2019).

Ministry of Finance of the Republic of Bulgaria (2019): Database. Category: Budget/Statistics. www.minfin. bg. (Accessed 10 August 2019).

Muir, D. - Weber, A. (2013): Fiscal Multipliers in Bulgaria: Low But Still Relevant. IMF Working Paper No. $\mathrm{WP} / 13 / 49$.

Myles, G. (2009): Economic Growth and the Role of Taxation. OECD Economic Department Working Paper No. 714.

Nantob, N. (2014): Taxation and Economic Growth: An Empirical Analysis on Dynamic Panel Data of WAEMU Countries. MPRA Paper No. 61370.

National Statistical Institute (2019): Database. http://www.nsi.bg. (Accessed 25 July 2019).

OECD (2008): Taxing Wages. 2006-2007. Paris: OECD. 
OECD (2009): The Effectiveness and Scope of Fiscal Stimulus. OECD Economic Outlook Interim Report. Paris: OECD.

OECD (2010): Fiscal Consolidation: Requirements, Timing, Instruments and Institutional Arrangements. OECD Economic Outlook 2010/2. Paris: OECD.

Oyinlola, M. A. - Adedeji, A. A. - Bolarinwa, M. O. - Olabisi, N. (2020): Governance, Domestic Resource Mobilization, and Inclusive Growth in Sub-Saharan Africa. Economic Analysis and Policy 65: 68-88.

Paparas, D. - Richter, C. (2015): Fiscal Policy and Economic Growth: Empirical Evidence from the European Union. International Network for Economic Research Working Paper No. 2015.06.

Patonov, N. (2016): Fiscal Impacts on Output in a Small Open Economy: The Case of Albania. Scientific Annals of Economics and Business 63(2): 161-169.

Schaltegger, C. A. - Torgler, B. (2006): Growth Effects of Public Expenditure on the State and Local Level: Evidence from a Sample of Rich Governments. Applied Economics 38: 1181-1192.

Schwellnus, C. - Arnold, J. (2008): Do Corporate Taxes Reduce Productivity and Investment at the Firm Level? Cross-country Evidence from the Amadeus Dataset. OECD Economics Department Working Paper No. 641.

Stoilova, D. (2017): Tax Structure and Economic Growth: Evidence from the European Union, Contaduría y Administración 62(3): 1041-1057.

Stoykova, A. - Paskaleva, M. (2018): Correlation Dynamics between Southeast European Capital Markets. Ikonomicheski Izsledvania 27(4): 49-82.

Szarowska, I. (2013): Effects of Taxation by Economic Functions on Economic Growth in the European Union. MPRA Paper No. 59781.

Tanchev, S. (2016): The Role of the Proportional Income Tax on Economic Growth of Bulgaria. Ikonomicheski Izsledvania 25(4): 66-77.

Todorov, I. (2014): Macroeconomic Trends in the New Member Countries of the European Union Before the Euro Area Debt Crisis. Analele Stiintifice ale Universitatii Al I Cuza din Iasi - Sectiunea Stiinte Economice 61(2): 197-217.

Transperancy International Bulgaria (2020): Corruption Perception Index. Database. http://transparency. bg/en/transp_indexes/indexes/. (Accessed 15 February 2020)..

Vartia, L. (2008): How Do Taxes Affect Investment and Productivity? Industry Level Analysis of OECD Countries. OECD Economics Department Working Papers No. 656.

Widmalm, F. (2001): Tax Structure and Growth: Are Some Taxes Better than Others? Public Choice 107: 199-219.

World Bank (2019): Database. Category: Data and Statistics/Country Groups. www.worldbank.org. (Accessed 19 August 2019).

Zipfel, F. - Heinrichs, C. (2012): The Impact of Tax Systems on Economic Growth in Europe: An Overview. DB Research EU Monitor 5 October.

Open Access. This is an open-access article distributed under the terms of the Creative Commons Attribution-NonCommercial 4.0 International License (https://creativecommons.org/licenses/by-nc/4.0/), which permits unrestricted use, distribution, and reproduction in any medium for non-commercial purposes, provided the original author and source are credited, a link to the CC License is provided, and changes - if any - are indicated. 